BJHS 53(2): 183-205, June 2020. @ The Author(s), 2020. Published by Cambridge University Press on behalf of British Society for the History of Science. This is an Open Access article, distributed under the terms of the Creative Commons Attribution licence (http://creativecommons. org/licenses/by/4.0/), which permits unrestricted re-use, distribution, and reproduction in any medium, provided the original work is properly cited.

doi:10.1017/S0007087420000023 First published online 03 April 2020

\title{
Eating game: proteins, international conservation and the rebranding of African wildlife, 1955-1965
}

\author{
RAF DE BONT*
}

\begin{abstract}
Around 1960, leading figures in the international conservation circuit-such as Julian Huxley, Frank Fraser Darling and E. Barton Worthington-successfully propagated new visions about the value of undomesticated African mammals. Against traditional ideas, they presented these mammals as a highly efficient source of protein for growing African populations. In line with this vision, they challenged non-interventionist ideals of nature preservation, and launched proposals for active management through game 'ranching' and 'cropping'. As such, they created a new socio-technical imaginary for Africa's future, in which the consumption of wildlife meat took up a central position. This article explores the motivations of Western conservationists for this drastic rebranding. It argues that the rationale of considering African wildlife in terms of protein played an important symbolical role at various levels. It was crucial in the reorganization of the transnational networks of conservation, but also in the boosting of their scientific reputation, in the restructuring of their institutional ties, and in their attempts to maintain an authoritative position for Western ecologists in a rapidly decolonizing world.
\end{abstract}

In 1962, the American wildlife ecologist Raymond F. Dasmann published an article in the journal Pacific Discovery. It carried the ominous title 'Conservation by slaughter'. In the article, Dasmann described the research he and two other American Fulbright scholars (Archie Mossman and Thane Riney) had carried out in Southern Rhodesia over the last years. Their goal had been to find out whether the 'cropping' of wild hoofed animals in marginal lands and the selling of their meat could be commercially profitable, and, if so, how the revenues compared to the practices of cattle ranching. The American wildlife ecologists carried out a pilot project at the ranch of Ian and Alan Henderson, and the results were positive. Cropping wild ungulates seemed indeed to be more lucrative than breeding cattle, and this, Dasmann argued, provided a strong argument for wildlife

* History Department, University of Maastricht, Grote Gracht 90-92, 6211 PG, Maastricht, the Netherlands. Email: r.debont@maastrichtuniversity.nl.

This article was written as part of the VICI project Moving Animals (VI.C.181.010), funded by the Netherlands Organization for Scientific Research (NWO). I would like to thank Bernhard Gissibl and Felix Schürmann for inviting me to the Decolonization and the Politics of Wildlife workshop, at which an early draft of this article was discussed. Kate Kangaslathi and two anonymous referees, furthermore, provided helpful feedback. 
conservation. Yet, despite the results, the tone of his article was far from jubilant. Dasmann suggested he had carried out his work only grudgingly: 'We were slaughtering great numbers of the most attractive animals on earth to prove to others with more authority that these animals should not be senselessly slaughtered.' And while he took an economic line of argument, he did so with great reluctance: 'It is a commentary on the overpopulation of our world to state that we have reached the point where dollarsand-cents arguments must be used to sell a program of wildlife conservation.' ${ }^{1}$

Dasmann made his claims about the potential economic prospects of wildlife cropping sound dramatic and radical. Yet while a decade earlier such ideas might have been controversial, by the time Dasmann published his article they had become widely accepted in the transnational conservation community. Around 1960, official documents of organizations such as the International Union for the Conservation of Nature and Natural Resources (IUCN) openly endorsed the idea that in Africa's supposedly brittle ecosystems wildlife could be an efficient producer of protein for human consumption. In the same years, several key players in international conservation circles, such as Julian Huxley, Frank Fraser Darling and Edgar Barton Worthington, actively promoted wildlife cropping and ranching as ecological alternatives to both traditional pastoralism and modern cattle ranching. In a period of only ten years, the consumption of wildlife meat had, to use the terminology of STS scholar Sheila Jasanoff, taken up a central position in the socio-technical imaginary of Western conservationists for Africa's sustainable future. ${ }^{2}$

The endeavour of sustainably 'harvesting' African wildlife has only lately attracted the interest of historians. This recent scholarship, while acknowledging the role of transnational networks of Western conservationists, has so far focused mostly on particular national or regional contexts. In a comprehensive study, Jane Carruthers has, for instance, analysed the history of game ranching in South Africa, indicating the ways in which it transformed the country's agricultural landscape throughout the twentieth century. ${ }^{3}$ Reuben Matheka, for his part, has studied wildlife cropping in relation to early forms of community-based conservation in Kenya in the 1950s and 1960s. ${ }^{4}$ Etienne Benson, finally, has shown how imaginaries of wildlife cropping intersected with scientific studies into animal territoriality in Uganda during its decolonization period. 5 This article builds on this extant scholarship, but also partially shifts the

1 Raymond Dasmann, 'Conservation by slaughter', Pacific Discovery (1962) 15(2), p. 3.

2 Jasanoff defines socio-technical imaginaries as 'collectively held, institutionally stabilized and publicly performed visions of desirable futures, animated by shared understandings of forms of social life and social order attainable through and supportive of advances in science and technology'. Sheila Jasanoff, 'Future imperfect: science, technology, and the imaginations of modernity', in Sheila Jasanoff and Sang-Hyun Kim (eds.), Dreamscapes of Modernity: Sociotechnical Imaginaries and the Fabrication of Power, Chicago and London: The University of Chicago Press, 2015, pp. 1-33.

3 Jane Carruthers, "Wilding the farm or farming the wild"? The evolution of scientific game ranching in South Africa from the 1960s to the present', Transactions of the Royal Society of South Africa (2008) 63 (2), pp. 160-181.

4 Reuben Matheka, 'The international dimension of the politics of wildlife conservation in Kenya, 19581968', Journal of Eastern African Studies (2008) 2(1), pp. 112-133.

5 Etienne Benson, 'Territorial claims: experts, antelopes, and the biology of land use in Uganda, 1955-75', Comparative Studies of South Asia, Africa and the Middle East (2015) 35(1), pp. 137-155. 
perspective. My focus will be on the symbolic role conferred upon game cropping within transnational networks of conservationists. The small group of (mostly British and American) conservationists who pushed the case of sustainable wildlife cropping not only hoped to transform the African food economy, but also wanted to transform the goals, approaches and aura of the international conservation movement. It is these two entangled projects that take centre stage here.

This article focuses on a small number of elite conservationists who considered themselves cosmopolitans who spoke the universal language of science, but remained embedded within the influence of the specific contexts in which they worked. African estates and protected areas where wild ungulates resided constituted only one of these working contexts, whether visited during short 'reconnaissance' trips (of only a few weeks) or observed over the course of longer research stays (up to a few years). Their work and ideas were additionally shaped by the context of the international conference circuit and the bureaucracies of transnational governmental and non-governmental institutions, as well as by the logic of Western universities, research institutes and funding agencies. Furthermore, many of the conservationists concerned also conducted field research in geographical contexts entirely different from those of sub-Saharan Africa and this research equally informed their imaginaries of what Africa might become. These men belonged to a travelling class, rich in transnational contacts and unafraid to devise policies for spaces far removed from their own places of work and residence.

In this article, I seek to explain the sudden shift in the approach that this cosmopolitan conservation elite assumed towards the protection of mammals in sub-Saharan Africa. In the period between 1955 and 1965, its members reframed African wildlife from an object that needed to be shielded from all human interference to a resource that was to be actively managed by humans. I will argue that an amalgamation of scientific, institutional and geopolitical factors contributed to this shift. Furthermore, I will use game cropping as a lens to understand how Western conservation networks tried to adapt to a rapidly changing world. This article argues that the commodification of wildlife, taking place under the umbrella of international organizations, provided a crucial means for these networks to prepare for and adapt to decolonization, in order to effectively retain control over the land and fauna in former colonies. As such, this study resonates with the interest of political ecologists and critical geographers, who stress the importance of capitalist processes of commodification, as well as of colonial legacies, for international conservation projects in today's Africa. ${ }^{6}$ The colonial and commodifying logic these critics observe in present-day conservation had already converged in the socio-technical imageries of wildlife cropping of the 1960s. And they did so in a particular way. By rebranding wildlife as an object of consumption, the 'novel' conservation philosophy actually served to perpetuate 'old' colonial positions of power.

6 The literature developing these claims is virtually endless. This article drew inspiration from Jim Igoe and Dan Brockington, 'Neoliberal conservation: a brief introduction', Conservation \& Society (2007) 5(4), pp. 432-449; William Adams and Martin Mulligan, Decolonizing Nature: Strategies for Conservation in a Post-colonial Era, London: Earthscan, 2009; Dan Brockington, Rosaleen Duffy and Jim Igoe, Nature Unbound: Conservation, Capitalism and the Future of Protected Areas, London: Earthscan, 2010; Dan Brockington and Rosaleen Duffy, Capitalism and Conservation, Chichester: Wiley Blackwell, 2011. 


\section{'Dynamic conservation' versus 'static preservation'}

The 'new approach to conservation in Africa', as Dasmann called it, was the brainchild of a small group of people. ${ }^{7}$ The intellectual leader of this group of 'new conservationists' was the Scottish 'naturalist-philosopher' Frank Fraser Darling. ${ }^{8}$ A specialist of the population dynamics of red deer and the author of several popular naturalist books in the interwar period, Fraser Darling was originally an outsider to the British scientific establishment. However, his position changed substantially when ecological circles in the United States increasingly started to reference his work from the late 1940s onwards. In 1956, capitalizing on his growing reputation as an ecological generalist, Fraser Darling obtained an invitation from the government of Northern Rhodesia to carry out a study tour as an ecological consultant. A series of other 'reconnaissance tours' to British Africa followed. It took him just a few years, if we can believe his contemporaries, to start dominating the field of African ecology, and he used this position to make the case for wildlife cropping and game ranching. ${ }^{9}$ While Fraser Darling was the main theorizer, two of his British acquaintances did most of the networking labour to promote the sustainable management of African wildlife. The first was Julian Huxley, the evolutionary biologist, public intellectual and former director of the United Nations Educational, Scientific and Cultural Organization (UNESCO), who was well connected in official and scientific circles on both sides of the Atlantic. The second was the ecologist and science administrator Edgar Barton Worthington, who, after many years as a researcher and development adviser in British Africa, became deputy director of the British Nature Conservancy in 1957.10 Together, Fraser Darling, Huxley and Worthington made up the intellectual and institutional backbone of the new paradigm.

Although established British scientists launched the idea of wildlife cropping as a conservation project for Africa, younger wildlife ecologists, many of them Americans, carried out most of the empirical fieldwork that substantiated it. A great number of these younger scientists came to Africa as Fulbright fellows in the late 1950s and early 1960s to work on ungulates. Apart from Dasmann, Mossman and Riney in Southern Rhodesia, these researchers included Wendell G. Swank, Helmut Buechner, William Longhurst and Irvin O. Buss in Uganda and George A. Petrides in Kenya. Simultaneously, Lee Talbot and Georg Treichel worked on the migrations and

7 Raymond Dasmann, African Game Ranching, New York: The Macmillan Company, 1964, p. 34.

8 Dasmann, for instance, indicated that he owed Fraser Darling a 'karmic debt'. Raymond F. Dasmann: A Life in Conservation Biology. Interviewed and Edited by Randall Jarrell, University of California: Regional History Project, University Library, 2000, p. 32, at https://escholarship.org/uc/item/4j9397s9.

9 Noel Simon, Between the Sunlight and the Thunder: The Wild Life of Kenya, London: Collins, 1963, p. 364. On Fraser Darling see J. Morton Boyd (ed.), Fraser Darling in Africa: A Rhino in the Whistling Thorn, Edinburgh: Edinburgh University Press, 1992; Kenneth Mellanby, 'Darling, Sir Frank Moss Fraser (1903-1979)', Oxford Dictionary of National Biography, Oxford University Press, 2004, at https://doi.org/ 10.1093/ref:odnb/30999.

10 For a good contextualization of Huxley's and Worthington's imperial activities see Peder Anker, Imperial Ecology: Environmental Order in the British Empire, 1895-1945, Cambridge, MA: Harvard University Press, 2001, pp. 196-218, 228-236; Marianne Sommer, History Within: The Science, Culture and Politics of Bones, Organisms, and Molecules, Chicago and London: The University of Chicago Press, 2016, pp. $207-231$. 
population dynamics of ungulates in the savannahs of Tanganyika with grants from the National Science Foundation and the Conservation Foundation respectively. ${ }^{11} \mathrm{~A}$ British-American network thus arose and proved crucial to pushing the agenda of cropping for conservation. Its ideas, however, resonated in the transnational network as a whole, and soon mobilized other Western scientists specialized in the ecology and management of wild ungulates, such as the Swedish zoologist Kai Curry-Lindahl, the French physiologist François Bourlière, and the Belgian ecologist Jacques Verschuren. ${ }^{12}$

These men came from varied backgrounds, but shared a common agenda. Nearly all situated themselves on the 'conservation' side of the preservation-conservation divide that, according to both historical actors and latter-day historians, had run through the global environmental movement since at least the nineteenth century. According to the terms of this divide, whereas 'preservation' aims to protect 'wilderness' in its unaltered state by shielding it from human influence, 'conservation' as an approach seeks the sustainable use of natural resources. ${ }^{13}$ In practice, however, this distinction is far from clear-cut, and, to complicate things further, the true meaning of these terms tended to shift, depending on the exact historical context in which they were used. ${ }^{14}$ In the 1950s and 1960s, they functioned particularly as strategical markers, serving the process of group formation and public relations. Notably, the proponents of 'conservation' stylized their own approach as 'modern', 'dynamic' and 'scientific' by distinguishing themselves from 'preservationists' whose ideas they framed as 'traditional', 'static' and 'sentimental'. 15

Admittedly, for a very long time Western lobby groups concerned with African wildlife chiefly assumed a prototypically 'preservationist' standpoint. They built partially on the romantic notions of white hunters in which Africa's interior was imagined as an unspoiled and pre-human Eden, threatened by both colonial development and 'poaching' by Africans. Imperial and (from the interwar years onwards) international preservation societies hoped to overcome these threats by pushing for hunting legislation and the establishment of reserves and national parks. The underlying logic was to separate people as much as possible from 'unspoiled' non-human nature. This logic motivated early wildlife agreements among colonial powers, exemplified by the London

11 For overviews see George Petrides and Wendell G. Swank, 'The status of wildlife and wilderness Areas in East Africa', Oryx (1960) 5, pp. 295-306, 296; Frank Fraser Darling, 'African wildlife as a protein resource', Span (1961) 4, pp. 100-103, 103.

12 Bourlière François and Jacques Verschuren, Introduction à l'écologie des ongulés du Parc National Albert. I-H Exploration du Parc National Albert. Mission F. Bourlière et J. Verschuren, Brussels: Institut des parcs nationaux du Congo et du Ruanda-Urundi, 1959; Kai Curry-Lindahl, Contribution à l'étude des vertébrés terrestres en Afrique tropicale. I. Exploration du Parc National Albert et du Parc National de la Kagera. Mission K. Curry-Lindahl (1951-52, 1958-59), Brussels: Institut des parcs nationaux du Congo et du Ruanda-Urundi, 1961.

13 See, for instance, John McCormick, Reclaiming Paradise: The Global Environmental Movement, Bloomington: Indiana University Press, 1989, pp. 12-17.

14 See also Anker, op. cit. (10), p. 197.

15 For instance, Frank Fraser Darling, Wildlife in an African Territory, London: Oxford University Press, 1960, p. 2; Edgar Barton Worthington, 'Dynamic conservation in Africa', Oryx (1960) 5(6), pp. 314-345. See also the quote from Talbot in Martin Holdgate, The Green Web: A Union for World Conservation, London: Earthscan, 1999, p. 64. 
conventions of 1900 and 1933, and it inspired the lobbying of international civic preservation societies in the interwar years. ${ }^{16}$ These societies chiefly promoted a hands-off approach to nature protection that sought to fence off the primeval 'natural balance' from human interference. The idea was particularly successful in the French and Belgian colonies in Africa, where key players from international preservation circles succeeded in obtaining managerial roles in the national-parks administration. The so-called 'strict' or 'integral' nature reserves in French Madagascar and the Belgian Congo - reserves conceived as 'natural laboratories' in which scientists could study primitive nature in its unaltered state-epitomized the preservationist rationale. Killing animals in such reserves was out of the question. Until well into the 1940s, transnational preservationist societies actively associated themselves with this model. It is no coincidence that the International Union for the Protection of Nature (IUPN) chose JeanPaul Harroy, a former administrator of the national parks in Belgian Congo, as its first secretary general in $1948 .{ }^{17}$

At the same time, however, it is clear that after the Second World War the tone of discussions about nature protection gradually changed. The resource shortage experienced during the war, and the large-scale governmental planning deployed to tackle this scarcity, changed the way in which nature was conceptualized. Rapid population growth only added to the resource challenge, which became a major object of interest within the newly founded United Nations (UN) and its special agencies. When the Economic and Social Council (ECOSOC) of the UN organized a high-profile conference on natural resources in Lake Success in 1949, the IUPN set up its first technical meeting at the same location in order to tap into this momentum. ${ }^{18}$ Huxley invited Fraser Darling, at that point still working on Scottish land degradation, to be one of the attendants. In the lounge of the Lake Success conference building, the latter liaised with the leading figures of the American conservation movement, including A. Starker Leopold, Fairfield Osborn Jr and William Vogt. ${ }^{19}$ These three men not only advocated

16 The historiography on wildlife policies in late nineteenth- and early twentieth-century colonial Africa is too extensive to review here. Key publications include John M. MacKenzie, The Empire of Nature: Hunting, Conservation and British Imperialism, Manchester and New York: Manchester University Press, 1988; Roderick Neumann, 'Dukes, earls and ersatz Edens: aristocratic nature preservationists in colonial Africa', Environment and Planning D: Society and Space (1996) 14, pp. 79-98; William Adams, Against Extinction: The Story of Conservation, London and New York: Earthscan, 2004; Bernhard Gissibl, The Nature of German Imperialism: Conservation and the Politics of Wildlife in Colonial East Africa, New York and Oxford: Berghahn, 2016; Jane Carruthers, National Park Science: A Century of Research in South Africa, Cambridge: Cambridge University Press, 2017; Jeff Schauer, Wildlife between Empire and Nation in Twentieth-Century Africa, Cham: Palgrave Macmillan, 2019.

17 With regard to the preservationist ideals in the French and Belgian colonies see respectively Caroline Ford, Natural Interests: The Contest over Environment in Modern France, Cambridge, MA and London: Harvard University Press, 2016; Raf De Bont, 'A world laboratory: framing the Albert National Park, 1925-1961', Environmental History (2017) 22, pp. 404-432.

18 On the wider context see Anna-Katharina Wöbse, “"The world after all was one”: the international environmental network of UNESCO and IUPN, 1945-1950', Contemporary European History (2011) 20 (3), 331-348.

19 Frank Fraser Darling, Pelican in the Wilderness: A Naturalist's Odyssey in North America, New York: Random Press, 1956, p. 18. 
an active form of 'game management' that allowed for human intervention, but also connected their stance to the wider issue of human dependence on natural resources. ${ }^{20}$ 'The human factor', Vogt stressed at Lake Success, 'can no more be excluded from the protection of wildlife than it can be from the conservation of water, soil, hydro-electric or other resources. ${ }^{21}$ This position tied nicely with Fraser Darling's own ideas.

It was not until the mid-1950s, however, that the 'New Conservationist' perspective became dominant within the IUPN, and the union's general assembly in Edinburgh in 1956 was telling in that regard. It was Max Nicholson, director of the Nature Conservancy and a close friend of Huxley's, who had brought the assembly to the UK. This was significant in itself since the British had originally shown only little interest in the IUPN, focusing their attention in the late 1940s on establishing their own national conservation institutions. A decade later, however, the context had changed. In a memorandum for the British government, Nicholson explained that looming decolonization might lead to unprecedented environmental destruction. He added that in such circumstances 'only an international body such as IUPN can intervene acceptably with sufficient force and with full access to technical advice'. ${ }^{22}$ In order to ensure the success of such interventions, he not only hoped to involve the British more closely in the work of the organization, but also immediately attempted to change the IUPN from within. As director of the Nature Conservancy he had already pushed a broad environmental agenda that looked beyond 'wild' nature and included the management of rural landscapes. ${ }^{23}$ In Edinburgh, then, Nicholson managed to have the organization's name changed to the International Union for Conservation of Nature and Natural Resources (IUCN), supported by Fraser Darling and several American conservationists. ${ }^{24}$ The newly elected (and British) secretary general Tracy Phillips explained the rationale of the name change at length in a letter to a UNESCO colleague. He wrote,

There was a general agreement that since of the world's natural resources man is not the least, and since the whole eventual and main aim of the Union is for human welfare, there is no reason not to make clear the unavoidably sociological aspect of the Union's aim and activities, which should emphasize the constructive and the scientific rather than the negative and the prohibitive. $^{25}$

20 Thomas Robertson, The Malthusian Moment: Global Population Growth and the Birth of American Environmentalism, New Brunswick, NJ: Rutgers University Press, 2012, pp. 36-60.

21 International Technical Conference on the Protection of Nature: Lake Success, 22-29-VIII-1949, Brussels and Paris: International Union for the Protection of Nature, 1950, p. 35. See also Thomas Jundt, 'Duelling visions for the postwar world: the UN and UNESCO 1949 conferences on resources and the origins of environmentalism', Journal of American History (2014) 101, pp. 44-70.

22 Max Nicholson, 'The International Union for the Conservation of Nature-Memorandum by the Nature Conservancy', The National Archives, Kew Gardens, London - Colonial Office, Commonwealth and Foreign and Commonwealth Offices, CAB 1241599.

23 This is illustrated nicely by the discussion paper Nicholson presented at the technical meeting of the IUPN in Amsterdam 1951. Max Nicholson, 'Rural landscapes as a habitat for flora and fauna in densely populated areas: an introduction', City Archives, Amsterdam, Archives of the Dutch Commission of International Nature Protection, 1283-226.

24 Holdgate, op. cit. (15), pp. 63-65.

25 Tracy Phillips to C.M. Berkeley, 15 January 1956, UNESCO Archives, Paris, 502.7 A 01 IUCNNR ' -6 ' Part, Map VII. 
As far as African wildlife was concerned, it was largely Fraser Darling, Worthington and Huxley who, in the years to follow, were to put flesh on the bones of this selfproclaimed 'constructive' and 'scientific' approach. In their New Conservation, game cropping would take a central role. Rather than starting from scratch, however, they drew on a long and varied tradition of ecological theory building.

\section{Old science in new bottles}

While they associated their 1950s work in Africa with 'new ecological thinking' (Worthington), the 'rapid rise of ecological science' (Huxley) or an 'ecology of land use ... still in its infancy' (Fraser Darling), it is clear that the key aspects of their reasoning date back until at least the interwar years. ${ }^{26} \mathrm{~A}$ first major source of inspiration for their 'new' approach to conservation was the 1920s work of the Oxford animal ecologist Charles Elton. A former assistant to Huxley, Elton quickly rose to fame in the interwar years with his studies of the fluctuation of Arctic animal populations such as lemmings. In a series of reports and books, Elton explained these fluctuations in terms of food chains, in this way focusing not only on the interrelationship between various species of animals, but also on the relations between those species and the humans who hunted them. ${ }^{27}$ With this approach, he influenced his former supervisor, Huxley, as well as several generations of future British and American ecologists, including Worthington, Fraser Darling and Dasmann..$^{28}$ Due largely to Elton's work, these men went on to conceive African wildlife conservation as matter of 'this human ecology', a term Elton used regularly. ${ }^{29}$ Although rooted in 1920s discourse, human ecology still clearly inspired socio-technical imaginaries about Africa four decades later. Writing about African wildlife management in 1964, Huxley stated that he believed that scientists were finally 'on the brink of a new phase, of planned human ecology, which attempts to achieve an optimum relation between human life and the resources it needs'. ${ }^{30}$ Wildlife was conceived to be one of these resources.

In addition to Elton's work, the writings of the American ecologist Aldo Leopold (father of the aforementioned A. Starker Leopold) were a major source of inspiration in rethinking African conservation in the 1950s. A forester by training, Aldo Leopold had gained particular renown as the founding father of the discipline of 'game management' in the 1930s. Like Elton, Leopold was interested in the population dynamics of animals, which he linked both to questions of hunting and to issues of habitat availability

26 Fraser Darling, op. cit. (15), p. 5; Worthington, op. cit. (15), p. 345; Julian Huxley, The Conservation of Wild Life and Natural Habitats in Central and East Africa, Paris: UNESCO, 1961, p. 12.

27 See Peter Crowcroft, Elton's Ecologists: A History of the Bureau of Animal Population, London and Chicago: The University of Chicago Press, 1991; Anker, op. cit. (10), pp. 89-107.

28 Both Worthington and Fraser Darling acknowledged Elton's influence in their autobiographical writing. See Boyd, op. cit. (9), p. 13; Raymond Dasmann, Called by the Wild: The Autobiography of a Conservationist, Berkeley and Los Angeles: University of California Press, 2002, p. 75.

29 Fraser Darling, op. cit. (15), pp. 3-4; Julian Huxley, 'Wild life as a resource', North American Review (1964) 249(1), pp. 37-41, 41; Edgar Barton Worthington, The Ecological Century: A Personal Appraisal, Oxford: Clarendon Press, 1983, p. 97.

30 Huxley, op. cit. (29), p. 41. 
and soil degradation. Crucial to Leopold's philosophy was the concept of 'carrying capacity', namely the maximum population size of a species that a given environment can indeterminately sustain. He applied the notion to, amongst other things, the wellknown case of the deer populations of the Kaibab plateau in Arizona, which, after federal authorities had exterminated the local wolves, irrupted in the 1920s. This, Leopold argued, had led to the destruction of the vegetation cover, the degradation of the soil and, ultimately, the collapse of the deer population. In Leopold's version, the Kaibab plateau offered a cautionary tale of how human intervention could undercut the carrying capacity of particular environments. ${ }^{31}$

British and American ecologists drew on Leopold and Elton to put forward a very concrete argument. Fraser Darling's main point-Huxley, Worthington and the 'Fulbright wildlife ecologists' were to follow his lead - was that cattle differed from local wildlife in that they more easily outstripped the carrying capacity of Africa's soil. In addition to the aforementioned literature, Fraser Darling used early twentieth-century plant ecology to assert his claim. Over time, he argued, so-called 'climax communities' had arisen, ecologies that represented the most complex and diverse forms of life possible within the physical constraints of a set environment. In Africa, he believed, this had led to the evolution of animals that were both highly adapted to the vegetation of the continent's poor soils and highly diversified in terms of species, in order to make the best use of the mixed vegetation at their disposal. Imported sheep, goats and cattle not only lacked a similar evolutionary adaptation to the local plant cover, but also fed almost entirely on grass and in this way easily damaged both vegetation and soil. ${ }^{32}$

Fraser Darling's reasoning was not new. The Belgian botanist Jean Lebrun, for instance, developed quite similar ideas during his research in the Belgian Congo in the 1930s. ${ }^{33}$ What was new in Fraser Darling's version, however, was the metaphorical language he used to make his point. In line with the ecosystems ecology that was newly in vogue in the US in the 1950s, he assessed the role of wildlife in the cycle of both chemicals and energy through the ecosystem and in so doing turned to Alfred J. Lotka's concept of the 'conversion cycle'. 34 'Each species', Fraser Darling indicated, 'is concerned with the conversion of matter and ... the collective activities and effects of organisms indicate a direction of organic evolution towards maximum energy intake from the sun and maximum outgoing of free energy by dissipative processes'. In the same vein, Fraser Darling spoke of an evolutionary increase in the 'metabolic rate' of the ecosystem, of

31 Aldo Leopold, Game Management, New York: Scribner's Sons, 1933; Thomas R. Dunlap, Saving America's Wildlife, Princeton, NJ: Princeton University Press, 1988, pp. 65-74; Curt D. Meine, Aldo Leopold: His Life and Work, Madison: University of Wisconsin Press, 1988, p. 34; Robertson, op. cit. (20), pp. 23-29.

32 Frank Fraser Darling, 'Wildlife husbandry in Africa', Scientific American (1960), 203(5), pp. 123$143,126$.

33 Despite existing transimperial connections, his book on the topic, published in 1947, seems to have hardly been read in Anglo-American circles. Jean Lebrun, La végétation de la plaine alluviale au sud du lac Edouard, Brussels: Institut des parcs nationaux du Congo belge, 1947, 2 vols.; Kai Curry-Lindahl, 'The conservation story in Africa during the 1960s', Biological Conservation (1974) 6(3), pp. 170-178, 171.

34 See, amongst others, Sharon E. Kingsland, The Evolution of American Ecology, 1890-2000, Baltimore: Johns Hopkins University Press, 2005, pp. 185-199. 
climaxes representing 'the maximum energy flux in any set of physical and climatic conditions', and of 'bottlenecks' in the cycle created by fire and pastoralism. According to his model, the most efficient convertor of energy, and thus producer of protein, was the original wildlife of the region. ${ }^{35}$

Fraser Darling's vision of the role of African wildlife in the conversion cycle took shape well before his first actual visit to the continent in 1956 and sprang from more than simply his reading of Lotka. Fraser Darling's 'attitude of mind', to use his own expression, was also heavily informed by the ecological work he carried out in geographical contexts far removed from Africa, notably in the Scottish Highlands and Alaska. ${ }^{36}$ In the 1940s, he had led the government-ordered West Highland Survey, the report of which he finally published in 1955 as 'a study in human ecology'. The survey described the ecological effects of 'a primitively living group coming into fairly sudden contact with a more developed society'. In Fraser Darling's view, the consequences of this contact had been a rapidly rising human population, overgrazing through newly introduced sheep, land degradation and, ultimately, population decline. ${ }^{37}$ In Alaska, which he visited on a study tour with Starker Leopold in 1952, he observed similar phenomena. This time Fraser Darling wrote about semi-domesticated reindeer introduced from Siberia in the late nineteenth century that, unchecked by the largely exterminated predators, overgrazed the tundra. ${ }^{38}$ Both the Scottish Highlands and the Alaskan tundra offered him a template to interpret the African savannahs and steppes. The cross-geographical comparisons are ubiquitous in his field notes from Northern Rhodesia and they also return in his published work. In Fraser Darling's reasoning, African cattle were equivalent to Scottish sheep or introduced Siberian reindeer in Alaska: they were a bottleneck in the conversion cycle. ${ }^{39}$

In the 1950s, through comparisons drawn from other continents, ecologists found both templates to understand the bottlenecks presumed to afflict African ecosystems, and imaginaries to overcome them. By the 1960s, the model they most often referred to as a potential solution was, perhaps surprisingly, the USSR. More in particular, they drew inspiration from the Soviet management of the saiga antelope on the Central Asian steppes with which they had become acquainted through the work of their fellow IUCN member Andrej Bannikov. In an extensive monograph on the topic, Bannikov explained how the species had almost been hunted to extinction by 1917 , but also how careful biological management brought numbers back up to two million

35 Fraser Darling, op. cit. (15), pp. 6-7, 93-96; Fraser Darling, op. cit. (32), p. 127. Huxley, op. cit. (26), p. 28 , would use exactly the same imagery.

36 Boyd, op. cit. (9), p. 8.

37 Frank Fraser Darling, West Highland Survey: An Essay in Human Ecology, Oxford: Oxford University Press, 1955, p. 69. For the context in which the survey took place see Mark Toogood, 'Ecology and rehabilitation: The West-Highland Survey, 1944-1955', in Raf De Bont and Jens Lachmund (eds.), Spatializing the History of Ecology: Sites, Journeys, Mappings, London: Routledge, 2017, pp. 99-118.

38 A. Starker Leopold and Frank Fraser Darling, Wildlife in Alaska: An Ecological Reconnaissance, New York: Ronald Press, 1953.

39 E.g. Boyd, op. cit. (9), pp. 97, 116; Fraser Darling, op. cit. (15), pp. 85, 109; Fraser Darling, op. cit. (11), p. 101. 
by 1960 , thus laying the foundation for an economically significant form of sustainable cropping. Western ecologists were impressed. ${ }^{40}$ Dasmann, for instance, noted in 1963 that the antelope contributed no less than ' 6000 metric tons of first-class meat to the Soviet economy each year', in this way proving that ecological theory 'could actually work in practice'. ${ }^{41}$

Referencing US, Scottish and Soviet research, the international networks of conservationists drew their inspiration from across the globe when developing their ecological vision for Africa. Surprisingly perhaps, they were only to a limited degree informed by practical experiences on the ground. Notably in South Africa, agricultural and scientific circles had clearly engaged with the topic of game ranching before the advent of Fraser Darling and his followers. South African landowners had a tradition of allowing some wildlife on their farms that can be traced back to at least the 1930s, and, two decades later, also some local zoologists warmed to the idea. ${ }^{42}$ The transnational networks of conservationists were not entirely oblivious to local experiences, but it is clear that they mostly drew their inspiration from other sources. ${ }^{43}$ It is telling that when, in an article of 1964, Huxley brought up the possible combination of farming and game cropping, he explicitly expressed his 'surprise' that a substantial number of farms in the Transvaal region actually had concrete experience with such a mixed farming business. ${ }^{44}$ After all, like most of his conservationist friends in Britain and the US, Huxley built his imagery for Africa on globally circulating theories, rather than on localized experience.

While only giving limited attention to existing expertise in East and Southern Africa, men such as Fraser Darling, Huxley and Worthington were eager to set up place-based

40 Bannikov's saiga monograph came out in Russian in 1961. Several Western media outlets took note at the time, and it was translated in its entirety into German (1963) and English (1971). Andrej Bannikov, Biologija sajgaka, Moscow: Izdat. Sel'skochozjajstvennoj Literatury Žurnalov i Plakatov, 1961; William Linnard, 'The saiga', Oryx (1963) 7, 30-33; Huxley, op. cit. (29), p. 40; Dasmann, op. cit. (7), pp. 39-40; Frank Fraser Darling, 'The forward look in conservation', BBC Reith Lectures, 1969, www.bbc.co.uk/ programmes/p00h3xk5, min. 20.

41 Dasmann, op. cit. (7), pp. 39-40.

42 Bengt Lundholm, 'Game farming: is it a feasible proposition?', African Wildlife (1952) 6(2), pp. 121-128; William Beinart, The Rise of Conservation in South Africa: Settlers, Livestock and the Environment 1770-1950, Oxford: Oxford University Press, 2003, p. 385; Dawn Nell, 'The development of wildlife utilization in South Africa and Kenya, c.1950- 1990', DPhil diss., University of Oxford, 2003, pp. 101-106; Carruthers, op. cit. (3), pp. 165-166; Wouter van Hoven, 'Private game reserves in Southern Africa', in René van der Duim, Maghiel Lamers and Jakomijn van Wijk (eds.), Institutional Arrangements for Conservation, Development and Tourism in Eastern and Southern Africa, Dordrecht: Springer, 2015, pp. 105-106.

43 One notable exception was the Swedish mammologist Bengt Lundholm (employed by the Transvaal Museum in Pretoria), to whom both Dasmann and Mossman referred as prompting their own work in Rhodesia. Yet, all the same, Dasmann later made clear that the actual idea of setting up their Rhodesian research directly came from Darling. In his memoirs, he only mentions Lundholm once (and, maybe indicatively, misspelled his name). Raymond F. Dasmann, op. cit. (8), p. 32; Dasmann, op. cit. 28, p. 98; Carruthers, op. cit. (3), p. 160.

44 Huxley, op. cit. (29), p. 39. In his Science in the Development of Africa, Worthington did mention the game ranching of 'one or two species' in the Transvaal, but only in passing. Edgar Barton Worthington, Science in the Development of Africa: A Review of the Contribution of Physical and Biological Knowledge South of the Sahara, Hertford: Austin, 1958, p. 331. 
research in the region themselves. Their calls for funding such research, formulated in the language of up-and-coming ecosystems ecology, proved successful, and place-based research was under way from the late 1950s onwards. Ecologists set up large-scale aerial censuses to assess the numbers of African ungulates, their population density and migrations; they initiated quantitative research to calculate their 'biomass'; and they launched practical programmes to organize commercialized slaughter. ${ }^{45}$ By 1960, at the very least the population density of Western wildlife ecologists in African savannahs and steppes was clearly on the rise.

\section{Institutional dynamics}

The New Conservation approach (symbolized by ungulate cropping) clearly tied in with the scientific sensibilities of the time, but in order to be successful, it also needed institutional embedment. Within the small circle of the IUCN, the approach of Huxley and Fraser Darling prevailed relatively quickly. In 1960, the general assembly in Warsaw flagged the plight of African megafauna as the IUCN's most urgent concern, with the organization's president, Jean Baer, stressing that 'the unreasoned massacre of fauna' had to give way to 'its rational exploitation'. ${ }^{46}$ Yet the IUCN was a small organization, comprising a limited group of Western scientists and with scarce financial means. Therefore many believed that in order to scale up conservation action in Africa the institutional landscape had to be further redrawn.

In a long letter to Huxley in July 1960, Nicholson explained what he believed to be the state of affairs in the aftermath of the Warsaw general assembly. He noted that their particular approach to conservation had risen considerably in standing within the IUCN, due largely to the appointment of several of their close acquaintances (such as Worthington) to the organization's board. But he also pointed out several points of action. One was to win over the support of more affluent international organizations such as UNESCO, the Commission de coopération technique en Afrique sud du Sahara (CCTA) and the Food and Agriculture Organization (FAO) of the United Nations. Second, Nicholson stressed that Western conservationists needed an action plan with regard to decolonization. He indicated that with the move of the IUCN's headquarters from Belgium to Switzerland the organization had already shown awareness of 'the importance of being completely free of associations with colonialist powers'. Such an aura of neutrality, he suggested, would be key to providing international organizations with the authority to intervene in cases where Africa's protected areas were threatened by post-colonial chaos, a scenario many Western conservationists expected and feared. At the same time, Nicholson believed it necessary to start networking with the upcoming African elites. Given a lack of contacts on the ground, they had to start by locating 'the politicians, administrators and other people who are powerful in the new

45 For good overviews of this research see Dasmann, op. cit. (7); L.M. Talbot, W.A. Payne, H.P. Ledger, L.D. Verdcourt and M.H. Talbot, The Meat Production Potential of Wild Animals in Africa: A Review of Biological Knowledge, Farnham Royal, Bucks: Commonwealth Agricultural Bureaux, 1965.

46 Seventh General Assembly - Warsaw, June 1960: Proceedings, Morges: IUCN, 1960, p. 27. 
set-up [and who] are at all sympathetic or receptive to conservation ideas'. Nicholson reminded Huxley that they had ample experience with such a strategy from their time in the Post-war Aims Group, an unofficial body founded in 1939 with the self-appointed goal of planning both the war and post-war economies. He suggested that, in the Europe of 1939 as well as in the Africa of 1960, it was necessary to liaise with prospective leaders before they actually took power. ${ }^{47}$

The IUCN's foremost members acted in line with Nicholson's double strategy of reaching out simultaneously to other international organizations and to potential African leaders. This reaffirmed their framing of wildlife as a natural resource. Western conservationists believed that such discursive framing would both bring wild animals onto the radar of development-oriented organizations such as the FAO and turn them into an appealing topic for aspiring African politicians. ${ }^{48}$ The strategy reached a high point when, in 1960, a small IUCN working group under the leadership of Worthington set up the so-called Africa Special Project (ASP). The project was designed to foster ties with UNESCO, the FAO and the CCTA through a common scheme specifically intended 'to inform and influence the public opinion, through its leaders and responsible persons in governments, that the application of conservation practices, based on ecological knowledge, is in the best interest of all African countries'. An early working document earmarked the producing of 'crops of animal protein and other wild products on a sustained yield basis' as one of the key targets. ${ }^{49}$ In the same year, Fraser Darling one of the working group's members - summarized the idea in a letter to Huxley: 'What we have to get over to gov[ernmen]ts is that the issue is not men or wild animals, but that in most areas the presence of wild animals is helpful + that, in some, it will be a case of no bloody animals, no bloody men. ${ }^{50}$ With that logic in mind, the ASP set to work. ${ }^{51}$

Worthington and Huxley had carefully prepared the ground. Worthington toured East and Southern Africa for the Nature Conservancy in spring 1960 to talk to local government departments. Huxley undertook a similar tour to assess the wildlife situation for UNESCO in the summer of the same year. Building on Worthington's and Huxley's assessments, the ASP, then, formally began with its First Stage in September 1960. This consisted of Gerald G. Watterson, the FAO forest officer for Africa, touring sixteen African countries with the goal of 'spreading the news and gospel'. ${ }^{2}$ The IUCN leadership saw the mission as an important achievement, not so much for the contacts Watterson gained in Africa, but for the fact that the undertaking drew the FAO firmly into the network. Whereas previously the FAO's Forestry Division had focused almost exclusively on timber issues, from this point forward it increasingly also counted

47 Nicholson to Huxley, 27 July 1960, Julian Huxley Papers, Rice University Archives, Houston.

48 See e.g. Huxley to Bloemers, 2 March 1960, UNESCO Archives, Paris, 502.7 A 01 IUCNNR '-6' Part, Map XI; Huxley to Harold G. Coolidge, 25 May 1960, Julian Huxley Papers, Rice University Archives, Houston; Petrides and Swank, op. cit. (11), p. 301.

49 'African Special Project (ASP), 1960-1963', report of the IUCN working group, UNESCO Archives, Paris, 502.7 A 01 IUCNNR ‘-6’ Part, Map XI.

50 Fraser Darling to Huxley, 17 January 1960, Julian Huxley Papers, Rice University Archives, Houston, italicization original.

51 On ASP more generally see Holdgate, op. cit. (15), pp. 71-74.

52 Worthington to Huxley, 13 September 1960, Julian Huxley Papers, Rice University Archives. 
wildlife as one of its concerns. ${ }^{53}$ The FAO's fresh involvement also stimulated interest in the circles of UNESCO, which, spurred on by inter-agency competition, wanted to avoid the impression 'that conservation problems are more their domain than ours'. ${ }^{54}$

Stage II of the ASP comprised a conference in sub-Saharan Africa that brought together (mostly Western) ecologists with (mostly African) politicians. This set-up implied a drastic change of strategy in international conservation. The last major international conference on African fauna protection, held in Bukavu in 1953, had drawn only European and white South African representatives. ${ }^{55}$ During preparations for the IUCN's general assembly of 1960, organizers had discussed inviting 'black representatives of the tropical African republics and territories', but had ultimately decided that this was politically too sensitive. ${ }^{56}$ By the time of the ASP conference, however, the IUCN leadership, even from the early planning stages, considered the presence of 'indigenous Africans' as crucial. ${ }^{57}$ The conference, after all, had to convince African leaders that wildlife was, in the words of Huxley, a great source of 'Profit, Protein, Pride and Prestige'. ${ }^{58}$ As a location, the organizers chose the (still British) Protectorate of Uganda, but the local attorney general, who feared the conference might lead to UN interference in Ugandan affairs, proved uncooperative. Therefore the convenors ultimately chose Arusha in soon-to-be-independent Tanganyika as the conference site. ${ }^{59} \mathrm{At}$ a press conference in Paris, they announced that the conference's focus would be the scientific study of African wildlife, with the ultimate goal of 'simultaneously saving megafauna from destruction ... and efficiently helping Africans to improve their living conditions at the nutritional level'. ${ }^{60}$

The organizers made sure of a strong African presence at Arusha. Tanganyika's prime minister Julius Nyerere attended, along with several of his ministers and local Maasai 'chiefs', while other African countries also sent representatives - enigmatically indicated as 'Fellows' in the conference proceedings. The ecological specialists, however, apart from notable exceptions such as the British-trained Kenyan zoologist David Wasawo and the Togolese forest engineer Adolphe Agbekodo, were mostly Western. Flying in from cities in Europe and the US, these specialists extensively discussed 'wildlife as a source of food', but also highlighted its cultural, spiritual and touristic importance. The educational and moralizing tone of the talks reverberated in the conference excursions, which were intended to show 'good' and 'bad' examples of land use. The

53 Thane Riney, 'Wildlife conservation and management', Unasylva (FAO) (1971) 14, pp. 15-17.

54 Alain Gille, 'Memo', 27 July 1960, p. 5, UNESCO Archives, Paris, 502.7 A 01 IUCNNR '-6' Part, Map $\mathrm{XI}$.

55 Jean-Paul Harroy, ed., Troisième conférence internationale: Protection de la faune et la flore en Afrique, Brussels: Clarence Dennis, 1953, pp. 15-18.

56 M.C. Bloemers to Roger Heim, 11 February 1960; Heim to Bloemers, 18 February 1960, Roger Heim Papers, Muséum d'histoire naturelle.

57 Minutes of special executive meeting, IUCN, 10 January 1960, UNESCO Archives, Paris, 502.7 A 01 IUCNNR '-6' Part, Map XI.

58 Huxley to Victor Kovda, 11 August 1960, UNESCO Archives, Paris, 502.7 A 01 IUCNNR ‘-6’ Part, Map XI.

59 Worthington to Huxley, 16 August 1960, Julian Huxley Papers, Rice University Archives.

60 'Conférence de presse', 24 July 1961, UNESCO Archives, Paris, 502.7 A 01 IUCNNR ‘-6’ Part, Map XII. 
'naturally balanced' environments of the nearby national parks served as examples of the first; the latter included the lands in Kenyan Maasailand, presented as suffering severe erosion from livestock grazing. ${ }^{61}$ Flyers aimed at broad audiences and written in both Swahili and English additionally stressed the importance of wildlife cropping and the 'hard cash' it provided. ${ }^{62}$ The take-home message of the conference's talks, field trips and leaflets was that international organizations were best capable of providing the technical expertise to make economic wildlife management work. Journalist John Hillaby deftly summarized the moral of the conference in an article in the New Scientist: 'What is wanted now is an effective world organization to take the lead in putting concepts into practice.' 63

Stage III of the ASP finally took place between 1961 and 1963 and consisted of a series of consultancy missions paid for by the FAO and carried out by Riney and the educationalist Peter Hill. These resulted, amongst other things, in a report designed to assist governments in balancing development with the conservation of natural resources. For a few more years, Africa remained the laboratory of the global conservation movement. American funding enabled the foundation of a College of African Wildlife Management in Mweka in Tanganyika to train African game wardens in $1963 .{ }^{64}$ In the same year, the IUCN held its general assembly in Nairobi (its first in Africa) and used the occasion to announce that it would continue to work 'along the lines that have led to the success of the Africa Special Project, in other parts of the world'. ${ }^{65}$ The FAO, in the meantime, further scaled up its African presence. By 1969, it had no less than fifty consultants travelling through the continent. ${ }^{66}$

The representatives of international conservation organizations definitely felt that they were achieving something. In a letter to Huxley, Fraser Darling wrote in 1961 of 'stirring days'. 'They are stirring', he explained, 'because we have got farther in the last year or two than for 30 years before'. ${ }^{67}$ The strategy they worked out together indeed seemed to pay off. The IUCN slowly integrated itself into a broader institutional landscape that included the UN's special agencies. Some of the most visible new leaders in Africa, including Nyerere and Kenya's prime minister Jomo Kenyatta, openly endorsed wildlife conservation - at least for the time being. ${ }^{68}$ And the transnational conservation

61 Gerald Watterson, ed., Conservation of Nature and Natural Resources in Modern African States: Report of a Symposium Organized by CCTA and IUCN and Held under the Auspices of FAO and UNESCO at Arusha, Tanganyika, September 1961, Morges: IUCN, 1963, pp. 96-108; Lee Talbot, Marty Talbot and Hugh Lamprey, An Introduction to the Landscape: Wildlife and Land Use Ecology and Conservation in Masailand and other Areas of the Southern Rift Valley and Central Provinces in Kenya and Northern Province, Tanganyika, Morges: IUCN, 1961.

62 'Kuuliza si unjinga? What is the answer?', August 1961, UNESCO Archives, Paris, 502.7 A 01 IUCNNR '-6' Part, Map XIII.

63 John Hillaby, 'The African conflict between man and animals', New Scientist (1961) 238, pp. 791-781.

64 McCormick, op. cit. (13), p. 45; Holdgate, op. cit. (15), p. 73.

65 Eighth General Assembly, Nairobi-Kenya-1963: Proceedings, Morges: IUCN, 1963, p. 43.

66 Riney, op. cit. (53), p. 17.

67 Fraser Darling to Huxley, 9 October 1961, Julian Huxley Papers, Rice University Archives, Houston.

68 On the position of Nyerere see in more depth Stephen Macekura, Of Limits and Growth: The Rise of Global Sustainable Development in the Twentieth Century, Cambridge: Cambridge University Press, 2015, pp. 57-61. 
community seemed to agree that their own role was that of natural-resource manager. Admittedly, there were still some dissenting voices. The German zoo director, filmmaker and media conservationist Bernhard Grzimek complained that the new approach was all too interventionist, leaving no room for actual 'wilderness' ${ }^{69}$ The director of Tanzanian national parks, John Owen, for his part believed that the international conservation movement too one-sidedly invested in scientific expertise. At the Arusha conference, he reputedly took the floor to exclaim, 'What I want are bullets and shells, and all I get are experts. ${ }^{70}$ Such dissent, however, remained marginal. By and large, Huxley, Fraser Darling and their allies had managed to streamline international conservation discourse; both ecological expertise and active resource management were at its core.

\section{Imagining Africa and 'the African'}

In the early years of the 1960s, the front-stage rhetoric of Western conservationists wedded ideas about the active management of African wildlife as a food resource to ideas about community involvement and African self-determination. ${ }^{71}$ These latter aspects, however, were added only belatedly and even then with great reluctance. Fraser Darling offers a case in point. In field notes made during his reconnaissance trips, he presented African participation in policy making as problematic at best. In 1956, while in Northern Rhodesia, he bluntly noted that 'the African is incapable of conservation sense'. ${ }^{72}$ In his published report, he did mention 'an element' among the African population that was conservation-minded, but he situated this 'in the vast undifferentiated magma of habitat-destroying Africans'. Throughout, he criticized the British administration for being too 'soft' in their interaction with the local population, resulting in a 'breakdown of cultural discipline'. Fraser Darling promoted a strict 'paternalism', although he added that his view was 'liable to violent attacks as smacking of rank colonialism'. ${ }^{73}$ In line with these convictions, he originally opposed the idea that nationalpark revenues should flow back to local tribal authorities. He believed that national or even international authorities, not local communities, were in the best position to administer conservation. Not until 1960, with independence looming across the continent, did he change his mind. ${ }^{74}$

Fraser Darling's ideas might have been outspoken, but they were not uncommon. The conservationists behind the ASP shared a common fear that decolonization would result in the mismanagement of nature. As such, they believed that it was both crucial and urgent to change the attitudes of the African population. In a confidential report to

69 This criticism tied in with a broader disapproval of 'so-called wildlife management' as conceptualized in the US. Grzimek to Swank, 18 January 1963, Julian Huxley Papers, Rice University Archives, Houston.

70 Ian Michael Wright to Richard H. Nolte, 22 September 1961, Institute of Current World Affairs Archives, www.icwa.org/wp-content/uploads/2015/11/IMW-6.pdf.

71 One Arusha working document, for instance, referred to the 'maximum possible participation in management projects' of 'local communities'. Watterson, op. cit. (61), p. 20.

72 Boyd, op. cit. (9), p. 18.

73 Fraser Darling, op. cit. (15), pp. 11, 80, 99-100.

74 Boyd, op. cit. (9), p. 216. 
the Nature Conservancy, Worthington presented local opinion in 1960 as 'the nub of the African conservation problem to-day. ${ }^{75}$ From this perspective, the promotion of game cropping seemed to offer the most promising route for Western conservationists. Petrides and Swank, for instance, noted in an article in the conservation journal Oryx that 'controlled hunting available to local Africans ... certainly would increase African interest in the maintenance of a wildlife supply'. ${ }^{76}$ Such reasoning, of course, started from particular preconceptions about the psychology of 'the African'. In an unsigned working document for the Arusha conference, these preconceptions become very explicit:

The African is a realist. The use of game as a source of food is not only more easily understood than the idea of conserving wild animals for aesthetic, scientific or sentimental reasons ... it also fulfils in many instances a strong instinct and a way of life and, if properly controlled, provides the most effective instrument of management. ${ }^{77}$

It is clear that the ecologists gathered in Arusha saw themselves as the ones to provide this 'proper control'.

Alongside the discursive strategy representing the African as a 'realist' and wildlife cropping as the most efficient way of providing protein, Western conservationists developed a second, seemingly contradictory discourse. In line with the ideas of the French naturalist-philosopher Théodore Monod, they regularly stressed that in a distant, 'traditional' past, Africans had actually lived in equilibrium with nature. ${ }^{78}$ Such a narrative largely blamed colonialism for having introduced an exploitative attitude, but, according to several IUCN spokespersons, an older, more spiritual attitude still lingered. Discussing the standpoint of 'the African' at the Arusha conference, Watterson suggested that there were 'clear indications that deep down his traditional bonds with nature are strong, and that lore and custom will again emerge in African culture'. The Arusha report similarly expressed the belief that 'the tide of sheer utilitarianism' could be stemmed. Such rhetoric seems, at first glance, at odds with the technocratic and utilitarian arguments usually deployed to defend wildlife cropping. In practice, however, Western conservationists cleverly merged both forms of discourse. The Arusha report stated that in order to reconnect Africans with their inner conservationist it was necessary, first, to 'improve the standard of living' and, second, to provide scientifically inspired guidance. ${ }^{79}$ The latter idea legitimized calls for large-scale ecological propaganda. Huxley, for instance, thought of documentary films, film strips, radio talks and wall charts as well as school excursions to national parks and the establishment of museums. Like many of his fellow conservationists, he furthermore stressed the importance of training specialized African wildlife ecologists. ${ }^{80}$ Behind the scenes, Western conservationists tried rapidly to organize such training before decolonization took hold. In

75 Edgar Barton Worthington, 'Confidential. The Nature Conservancy-Scientific Policy Committee. Summary Report', 23 March 1960, Julian Huxley Papers, Rice University Archives, Houston.

76 Petrides and Swank, op. cit. (11), p. 301.

77 Watterson, op. cit. (61), p. 21.

78 Théodore Monod, 'Man's dependence on nature and her resources', in Watterson, op. cit. (61), pp. 242246.

79 Watterson, op. cit. (61), p. 54.

80 Huxley, op. cit. (26), pp. 99, 105. 
1960, Worthington wrote in his confidential report that "with the "Africanisation" of Government services coming to the fore, there is wide realisation of the need for establishing a tradition of training while the opportunity still exists'. In this respect, he particularly saw Makerere College in British Uganda as an example to emulate. After all, the college provided what Worthington described as a 'steady output of disciplined Africans' ${ }^{81}$

The ambivalent relationship of Western conservationists with 'traditional' Africa found a corollary in their socio-technical imaginaries for the continent. They often stressed that the advent of Western technology - ranging from guns to bulldozers to veterinary medicine - was at the root of wildlife destruction. Fraser Darling, for instance, wrote in 1961 of 'an intoxication with technology' that spread over the continent, generating visions of a 'bush bulldozed into agricultural production'. ${ }^{82}$ Yet, although British and American ecologists had romantic visions of climax communities preceding the advent of modern technology, they hoped to restore that which they thought lost through management systems that were themselves highly technological. They wished to deploy airplanes to drive herds, trace poachers, perform aerial surveys and transport meat, and counted on using refrigerator facilities and mobile processing plants, as well as drugs to immobilize large mammals and antibiotics to spray the bush. ${ }^{83}$ At the same time, they looked for ways to fuse technological management schemes with 'tribal' traditions. Again, this hybrid approach was highly pragmatic. European and American conservationists working in Africa feared that the advances of veterinary science would open up marginal lands infested with tsetse flies to pastoral groups who had (or would receive) local autonomy. In such a context, community-supported cropping schemes could avert the advance of domestic livestock. Petrides and Swank, for example, were very open about the rationale of their approach. Given that 'tsetse areas' would soon be 'occupied as tribal lands', they believed that cropping schemes could provide an 'insurance against failure of the national-park approach in a politically uncertain environment'. ${ }^{84}$

By 1960, the group of ecologists around Fraser Darling, Huxley and Worthington had constructed a clear image of what modern conservation in Africa should look like. They conceptualized an active management of 'marginal lands' that efficiently produced food, that involved the local population as much as possible, that was regulated by ecological science and that was carried out by up-to-date technological means. It proved hard, however, to turn the rhetoric into something concrete. Cropping initiatives only materialized at a few 'experimental' sites, and even these often diverged from the ideal type. ${ }^{85}$

81 Edgar Barton Worthington, 'Confidential', 23 March 1960, Julian Huxley Papers, Rice University Archives, Houston.

82 Fraser Darling, op. cit. (32), p. 124.

83 Fraser Darling, op. cit. (32), p. 133; Thane Riney, 'The international importance of African wildlife', Unasylva (FAO) (1961) 15, 75-80; François Bourlière, 'Conservation and management of game stock', in $A$ Review of the Natural Resources of the African Continent, Paris: UNESCO, 1963, pp. 395-401.

84 Petrides and Swank, op. cit. (11), p. 303.

85 For the term 'experimental' see Worthington, op. cit. (15), p. 345. For more about the role of such an 'experimental' approach in the rise of the colonial and post-colonial development paradigm in Africa see Christophe Bonneuil, 'Development as experiment: science and state building in late colonial and postcolonial Africa, 1930-1970’, Osiris (2000) 15, pp. 258-281. 
One of the experimental sites often cited was the Queen Elizabeth National Park in Uganda. As early as the mid-1950s, the park administration believed that the hippo population exceeded the park's carrying capacity and, in 1956, it flew in Petrides and Swank to study the problem. When they recommended culling, the park's managers passed the suggestion to the IUCN, which set up a broadly conceived consultation in the form of a questionnaire sent to ecologists and wildlife managers across the world. The responses showed the extent to which the new conservation ethos had already taken root. While some respondents - not coincidentally mostly Belgians - stuck to the preservation ideal of non-interference, the great majority believed that culling was indeed necessary and urgent. ${ }^{86}$ The park staff effectively started the cropping of hippos in 1958 and they sold up to three thousand tons of meat through local contractors. Soon after, similar schemes followed elsewhere in Uganda for cropping kob antelopes and elephants. ${ }^{87}$

Simultaneously, Noel Simon, head of the Kenya Wildlife Society and a close friend of Fraser Darling's, initiated the so-called Galana River Game Management Scheme in Kenya. Involved in the heavy anti-poaching campaigns in the Tsavo National Park throughout the 1950s, Simon sought a way to reintegrate convicted Waliangulu 'poachers' after their prison sentence. In 1960, he set up a system of cropping elephants in a buffer zone around the park, in order to provide 'cheap protein' and to find a legal occupation for the Waliangulu in line with 'their traditional mode of life'. Much hyped in conservation circles, the scheme was problematic from the beginning, with Simon complaining about the limitations of staff, the low prices received for meat and the relative disinterest of the Waliangulu. Like the cropping schemes in Uganda, it also remained a project very much centred on a national park and led by the park's staff. ${ }^{88}$

The ambitions of the new conservation approach, however, went beyond nationalpark management. Conservationists held high hopes that it could also inspire the management of natural resources in unprotected wilderness. Fraser Darling, Worthington and Huxley singled out the red lechwe (a widespread antelope) in Northern Rhodesia as a good source of protein, one which might be efficiently cropped if its scientific management was merged with traditions of communal hunting. ${ }^{89}$ Yet what conservationists wholly and freely envisioned failed to translate in real terms.

86 'Proposition de réduction d’hippopotames : Résumé des réponses', UNESCO Archives, Paris, 502.7 A 01 IUCNNR ‘-6’ Part, Map IX.

87 See George Petrides and Wendell G. Swank, 'Management of the big game resource in Uganda, EastAfrica', in Transactions of the 23rd North American Wildlife Conference, Washington, DC: Wildlife Management Institute, 1958, pp. 461-477; J.H. Blower and A.C. Brooks, 'Development and utilization of wildlife resources in Uganda', in Watterson, op. cit. (61), pp. 96-108; Clive Alfred Spinage, African Ecology: Benchmarks and Historical Perspectives, New York: Springer, 2012, pp. 615-673.

88 For an overview of the scheme see Noel Simon, 'The Galana management scheme', in Watterson, op. cit. (61), pp. 325-328. It was highlighted, amongst others, as a model in Fraser Darling, op. cit. (32), p. 126; Huxley, op. cit. (26), p. 78; Edgar Barton Worthington, 'Confidential', 23 March 1960, Julian Huxley Papers, Rice University Archives, Houston.

89 Fraser Darling, op. cit. (15), 112-116; Huxley, op. cit. (26), p. 50; Edgar Barton Worthington, 'Confidential', 23 March 1960, Julian Huxley Papers, Rice University Archives, Houston. 
Only in Southern Rhodesia did Dasmann and Mossmann get an actual cropping project off the ground beyond the confines of the national parks, using the aforementioned ranch of the Hendersons. In order to assess the available game at the ranch, Dasmann and Mossmann held so-called road-strip counts, to which they added sex and age classification counts as well as behaviour studies to estimate the game's 'productivity'. Based on this, they decided to shoot 450 large mammals, mostly consisting of zebra and impala. In order not to make the animals wary, they shot them from blinds or, during the night, using spotlights techniques, so they indicated, inspired by poachers. The meat was then subsequently marketed through butcheries in Bulawayo. On the basis of this experiment, the American researchers believed that, in the future, the ranch could definitely receive a greater net profit from game than from cattle ranching. ${ }^{90}$ It was a conclusion that resonated internationally. ${ }^{91}$ Adding to the appeal, Dasmann and Mossman indicated that their management regime could be extended from private European ranches to native reserves and national lands. ${ }^{92}$ In his memoirs, however, Dasmann would later indicate that an inclusion of black African communities in such cropping schemes had always been out of the question for the Southern Rhodesian authorities. ${ }^{93}$

By the eve of decolonization, men such as Fraser Darling, Worthington, Huxley and Dasmann had succeeded in creating a socio-technical imaginary for Africa that wedded technocratic land management to community involvement. Despite their haste, they did not succeed in translating this hybrid (and somewhat paradoxical) vision into reality before countries in sub-Saharan Africa proclaimed their independence. Experimental cropping schemes failed to include local communities to any substantial degree, and by the time independence came (in 1961 in Tanganyika, in 1962 in Uganda, in 1963 in Kenya, in 1964 in Zambia, and in 1965 in Southern Rhodesia), the results were still limited at best.

\section{Epilogue}

The project of African game cropping held high symbolic value for the international community of conservationists. It exemplified a shift from preservation to conservation, bearing witness to the inclusion of ecosystems ecology and the promise - eventually, at least-of community involvement. Yet underneath the rhetoric of change, continuities abide. In his autobiography, Worthington recounts how, in the days after the Arusha conference, he travelled with Huxley and Nicholson to the

90 Raymond F. Dasmann and Archie S. Mossman, 'Commercial use of game animals on a Rhodesian ranch', Wild Life (1961) 3(3), pp. 7-14; Dasmann, op. cit. (1), p. 7.

91 For instance, it directly inspired a cropping experiment by the veterinary scientist Rüdiger Sachs in Tanganyika's Serengeti National Park (1963-1966), for which Grzimek, despite his aforementioned qualms about American-style game management, secured German funding. Thomas M. Lekan, Our Gigantic Zoo: A German Quest to Save the Serengeti, Oxford: Oxford University Press, 2020, pp. 224-226.

92 Dasmann and Mossman, op. cit. (90), p. 7.

93 Dasmann, op. cit. (28), pp. 103-104. 
Ngongorongo crater, which counted among the most iconic places of Edenic Africa. $\mathrm{He}$ indicated that, once there, the British visitors 'marveled at the high sustained biological productivity of the crater's grassland' ${ }^{94}$ What they were looking at, obviously, were the great charismatic mammals that had been at the heart of the global preservation regime since at least the late nineteenth century. Repackaged in the language of 'sustained productivity', old preservation interests were thus maintained rather than challenged.

Of course, the story of African game cropping did not end with decolonization, but continued over the following decades. In a BBC radio lecture in 1969, Fraser Darling stressed that it had been 'surprising how quickly the scientific attitude caught on in Africa'. ${ }^{95}$ And indeed, not only expat scientists, but also a new generation of African game managers - including, for instance, the Ghanaian Emmanuel Asibey took up the cause of 'scientific' cropping and ranching. ${ }^{96}$ Game ranching in particular rose in popularity, notably in Southern Africa. Southern Rhodesia boasted some two hundred game ranches by the mid-1960s, at which point civil war temporarily curbed their growth. ${ }^{97}$ In the Republic of South Africa success was even more outspoken. As Jane Carruthers has indicated, the number of South African game ranches continued to grow from the 1960s onwards, exceeding five thousand in the early 2000s and covering up to 13 per cent of the land surface. ${ }^{98}$ Simultaneously, the extent of commercial game ranching on private lands also grew significantly in Namibia, Zimbabwe and Zambia. ${ }^{99}$

The development of game ranching did not, however, unfold according to the sociotechnical imaginaries of the Western conservationists in the 1960s. Many of their early 'experimental' sites ended in disappointment. As Reuben Matheka has recounted, the Galana River Scheme failed to generate substantial returns and the number of participants quickly declined. In 1967, the park administrators leased out the project to a private company before terminating it altogether. ${ }^{100}$ Cropping in Elizabeth Park continued until the 1970s, when political turmoil led to a breakdown of law and order and the

94 Worthington, op. cit. (29), p. 156.

95 Fraser Darling, op. cit. (40), min. 23.

96 See e.g. Emmanuel Asibey, 'Wildlife as a source of protein in Africa south of the Sahara', Biological Conservation (1974) 6(1), 32-39.

97 Dasmann, op. cit. (28), p. 106.

98 Carruthers, op. cit. (3), p. 160, cites numbers from the Amalgamated Bank of South Africa report from 2003.

99 William Wolmer, 'Wilderness gained, wilderness lost: wildlife management and land occupations in Zimbabwe's Southeast Lowveld', Journal of Historical Geography (2005) 31(2), 260-280; Jon Barnes and Brian Jones, 'Game ranching in Namibia', in Helen Suich, Brian Child and Anna Spencely (eds.), Evolution and Innovation in Wildlife Conservation: Parks and Game Ranches to Transfrontier Conservation Areas, London: Earthscan, 2008, pp. 113-126; Peter A. Lindsay, Jonathan Barnes, Vincent Nyirenda, Belinda Pumfrett, Craig J. Tambling, W. Andrew Taylor and Michael t'Sas Rolfes, 'The Zambian wildlife ranching industry: scale, associated benefits, and limitations affecting its development', Plos One 8 (2), at https://doi. org/10.1371/journal.pone.0081761.

100 Matheka, op. cit. (4), p. 127. 
crashing of the hippo population. ${ }^{101}$ In Southern Rhodesia, the Hendersons did continue game ranching for a while, but soon found that more was to be gained from 'organized safari hunting' than from 'cropping and hauling'. ${ }^{102}$ In an interview in the year 2000, Dasmann did not hide his distress about the ways things had evolved in the region where he had worked. 'The whole idea of game ranching', so he claimed, 'has been used to cover a whole multitude of sins'. He added that it had been 'very bad in many respects'. Dasmann referred, amongst other things, to exotic animals flown to the United States for trophy hunting, and to the failure to reintegrate wildlife into the economy of local African populations. ${ }^{103}$

While the practice of game ranching was growing, several conservationists have shown themselves increasingly critical about its overall conservation value. ${ }^{104}$ Others, like Dasmann himself, have indicated that current game ranching caters more to Western tourist consumption and sport hunting than to feeding local populations. A widely used ecological textbook from 2008 indicates that, while Darling's original idea seemed 'to be theoretically sound', 'attempts to demonstrate its validity since the 1960s have been unsuccesful'. ${ }^{105}$ In a recent overview, Brian Child and co-authors indicate that this is only logical, because 'in contrast to safari hunting, which is ecologically robust and profitable, commercial or subsistence wildlife meat production is ecologically risky and economically questionable'. ${ }^{106}$

Yet scientific longevity and economic viability are only two ways to measure the success of the socio-technical imaginaries developed in the 1950s and early 1960s. As this article has shown, these imaginaries also served other purposes. These included the reorganization of the transnational network of conservation, the boosting of its

101 Vincent Muwinaka, 'A recent bottleneck in the warthog and elephant populations of Queen Elizabeth National Park, revealed by a comparative study of four mammalian species in Uganda national parks', Animal Conservation (2003) 6, pp. 237-245.

102 Dasmann, op. cit. (28), p. 106. In East Africa, simultaneously, Grzimek's cropping initiative in the Serengeti 'confronted unexpected logistical bottlenecks, cost overruns, and unruly environmental conditions'. It was abandoned in 1965. Lekan, op. cit. (91), p. 226.

103 Raymond F. Dasmann, op. cit. (8), pp. 33-34.

104 While several conservationists continue to point out the benefits of 'wildlife-based land use' over cattle breeding (notably in terms of increasing wildlife population numbers), there also has been growing attention to adverse effects since at least the 1980s. Critics claim that it leads to genetic mixing, the disappearance of local adaptations and increased exposure to livestock diseases. Others highlight that most wildlife ranches increase human-wildlife conflicts, entail a focus on just a limited number of species in the ecosystem and stimulate illegal trade by commodifying game. See, among others, Richard Luxmoore, 'Game farming in South Africa as a source of conservation', Oryx (1984) 19(4), pp. 225-231; Charles Krebs, The Ecological World View, Berkeley: University of California Press, 2008, p. 362; Ross T. Pitman, 'The conservation costs of game ranching, Conservation Letters: A Journal of the Society of Conservation Biology (2017) 10(4), pp. 403413. For more optimistic assessments see P.A. Lindsey, C.P. Havemann, R.M. Lines, A.E. Price, T.A. Retief, T. Thebergen, C. Van der Waal and S.S. Romañach, 'Benefits of wildlife-based land uses on private lands in Namibia and limitations affecting their development', Oryx (2013) 47(1), pp. 41-53; Elizabeth F. Pienaar, Elena C. Rubino, Melville Saayman and Petrus van der Merwe, 'Attaining sustainable use on private game ranching lands in South Africa', Land Use Policy (2017) 65, pp. 176-185.

105 Krebs, op. cit. (104), p. 361.

106 Brian A. Child, Jessica Musengezi, Gregory D. Parent and Graham F.T. Child, 'The economics and institutional economics of wildlife farming on private land', Pastoralism: Research, Policy and Practice (2012) 2(18), at https://pastoralismjournal.springeropen.com/articles/10.1186/2041-7136-2-18“ 
scientific reputation, the restructuring of its institutional ties and the continuation of the authoritative position of Western ecologists in post-colonial Africa. The project of game cropping and ranching has definitely played an important symbolic role in advancing these various agendas. As such, it has certainly furthered the position of a particular group of British and American conservationists. 